\title{
37. THE UPPER AND MID-BATHYAL CENOZOIC OSTRACODE FAUNAS OF THE RIO GRANDE RISE FOUND ON LEG 72 DEEP SEA DRILLING PROJECT ${ }^{1}$
}

\author{
Richard H. Benson, Smithsonian Institution, Washington, DC \\ and \\ Jean-Pierre Peypouquet, Institut de Géologie et Océanographie, Université de Bordeaux, Talence, France
}

\begin{abstract}
From the study of the ostracodes of Sites 516, 517, and 518 in comparison with those of Sites 21, 22, and 357, we can show that a time lag (early to late Oliogene) existed between the formation of the deep water masses (mid-bathyal $\pm 2000 \mathrm{~m}$ ) and those of intermediate depths (upper bathyal $\pm 1000 \mathrm{~m}$ ). The ostracode faunas suggest that while the Antarctic Intermediate Water $\left(\mathrm{O}_{2}=4.5\right.$ to $\left.5 \mathrm{ml} / \mathrm{l}\right)$ was flowing through the Vema Trough to fill the northern basins, the returning less-dense, warmer water $\left(\mathrm{O}_{2}=3.5\right.$ to $\left.5 \mathrm{ml} / \mathrm{l}\right)$ originating in Tethys was being gradually displaced upslope.

Efforts to identify shallow (less than $200 \mathrm{~m}$ ) faunas were unsuccessful. No evidence of significant changes in paleodepth or close proximity to islands could be found that could not be better explained by water-mass changes.

Studies of the genera Poseidonamicus and Krithe suggest an important water mass change at about $14 \mathrm{Ma}$ (late middle Miocene), but the cause of this event is not yet understood.
\end{abstract}

\section{INTRODUCTION}

Thirty-five samples were examined from four holes $(516,516 \mathrm{~F}, 517$, and 518$)$ from DSDP Leg 72 ; the samples were primarily from calcareous layers ranging in age from Maestrichtian (Hole 516F) to early Miocene (Holes 516 and 518), Pliocene (Hole 517), and Quaternary. Ostracodes were found in 30 of the 35 samples ( 50 $\mathrm{cm}^{3}$ in size), and 1594 specimens were identified. The early Paleogene and Cretaceous faunas were the poorest; the Neogene samples contained faunas with as many as 262 specimens of nine different genera (typical of the diversity of deep-sea faunas).

In general the faunas grow in abundance from scarce in the shallow bathyal zones to abundant in mid-bathyal depths. These abundant faunas seem to have appeared later (early Miocene) in the shallow holes (especially Holes 516 and $516 \mathrm{~F} ; 1313 \mathrm{~m}$ ) than were found in previous much deeper drilling sites (Site 357, $2109 \mathrm{~m}$; Hole 20C, $4484 \mathrm{~m}$; Site 21, $2113 \mathrm{~m}$; and Site 22, $2134 \mathrm{~m}$ ). The deep, warm prepsychrospheric fauna that was found in the Upper Cretaceous and lower Paleogene sediments of Leg 3 (Holes 20C and 21) and Leg 39 (Sites 356, 357) were not found in the Site 516 holes that penetrated these levels.

Holes 516 and $516 \mathrm{~F}$ had the best continuous representation of ostracode faunas (Table 1), 1452 specimens found in 23 samples. No single sample had more than 10 species, although 28 genera in all were found. Except for Poseidonamicus and Krithe, the two most abundant and useful ostracodes, taxonomic determinations below the genus level were made only for the more distinct forms ( 15 species in all). In the cases of these two general exceptions, attempts were made to trace detailed morphologic changes that might show significant changes in

${ }^{1}$ Barker, P. F., Carlson, R. L., Johnson, D. A., et al., Init. Repts. DSDP, 72: Washington (U.S. Govt. Printing Office). the histories of the prevailing water masses. We were especially interested in the reactions of the ostracode fauna to the development of the Antarctic Bottom Water (AABW) and the North Atlantic Deep Water (NADW) masses.

This is the third study of the ostracodes collected in cores from the Rio Grande Rise region. The first (Benson, 1974), which included a general faunal study of Leg 3 compared to the first 75 sites of DSDP, identified the " 40 million year event" (the origin of the modern psychrosphere, subsequently identified at $\mathbf{3 8}$ million years by Kennett and Shackelton, 1976) and discovered the deep-ocean fauna that preceded the modern one. The second study (Benson, 1977) described the faunas of Leg 39 (Sites 356 and 357) and added more documentation of the evolution of Abyssocythere from Paleoabyssocythere, the origin of Poseidonamicus, and the seeming extinction of Atlanticythere (all at the time of the development of the psychrosphere).

A study of Leg 40 (Peypouquet and Benson, in press) shows the development of circulation patterns in the southeastern Atlantic, especially the patterns controlled by Walvis Ridge (also see Peypouquet and Benson, 1980, for a study of the modern fauna). The present study attempts to show the diachronous delay from deep to shallow water as these water masses are established in the southwestern Atlantic. Some remarks will be made about the impoverishment of the pre-Oligocene deep faunas of the American and Guiana Basin Regions. In all, a picture of both the gradual establishment of the ostracode faunas of the South Atlantic and of the histories of the water masses that affect the bottom fauna is emerging.

We are still in the early stages of learning about deepsea ostracodes. They are complex animals, by the usual standards of micropaleontology, and they seem to evolve on several levels simultaneously (architecturally, histologically, and in shape; Benson, 1975a, 1981). They also 
Table 1. Ostracode species-zone matrix for South Atlantic DSDP Site 516.

\begin{tabular}{|c|c|c|c|c|c|c|c|c|c|c|c|c|c|c|c|c|c|c|c|c|c|c|c|c|}
\hline \multirow[b]{3}{*}{ Taxa } & \multicolumn{24}{|c|}{$\begin{array}{c}\text { Geologic age } \\
\text { B-zone (Benson, 1975b) }\end{array}$} \\
\hline & \multicolumn{2}{|c|}{$\underline{\text { Cretaceous }}$} & \multirow{2}{*}{$\frac{\text { Paleocene }}{15}$} & \multicolumn{2}{|c|}{ Eocene } & \multicolumn{6}{|c|}{ Oligocene } & \multicolumn{8}{|c|}{ Miocene } & \multicolumn{3}{|c|}{$\begin{array}{c}\text { Plio- } \\
\text { Pleistocene }\end{array}$} & \multirow{2}{*}{$\begin{array}{c}\text { Total } \\
\text { specimens }\end{array}$} & \multirow{2}{*}{$\begin{array}{l}\text { No. of } \\
\text { samples }\end{array}$} \\
\hline & 09 & 09 & & 17 & 19 & 20 & 22 & 22 & 23 & 24 & 25 & $26-$ & 26 & $26+$ & 27 & 28 & 29 & 30 & 32 & 34 & 35 & 35 & & \\
\hline Unidentified fragments & 1 & 2 & & 3 & 2 & & & 1 & 1 & & & & & & & & & & & & & & 10 & 6 \\
\hline cyprids & & 1 & & 5 & 2 & & 4 & & 1 & & & & & & & & & & & & & & 13 & \\
\hline Cytherella & & & 1 & & & 16 & 4 & 4 & & 9 & 4 & 1 & 6 & 1 & 15 & 10 & 5 & 1 & & 1 & & & 78 & 14 \\
\hline Paracypris & & & 1 & 4 & & & & & & & 4 & 1 & & & & & & & & & & & 10 & 4 \\
\hline Krithe & & & & 3 & 1 & 4 & 2 & 4 & & 3 & 5 & 4 & 1 & 1 & 49 & 13 & 20 & 30 & 118 & 88 & 80 & 48 & 474 & 17 \\
\hline Henryhowella & & & & & 1 & 6 & & & 1 & 6 & 9 & 3 & 4 & 3 & 12 & 4 & 10 & 13 & 16 & 16 & 30 & 39 & 173 & 16 \\
\hline Bairdia & & & & & & & & 1 & & & & & & 1 & 6 & 1 & 38 & 1 & & & & & 48 & 6 \\
\hline Cythereis & & & & & & & & 1 & & & & & 1 & 1 & & & & & & & & & 3 & 3 \\
\hline Trachyleberis & & & & & & & 1 & & & 5 & 10 & & & & 1 & 1 & 5 & 6 & 4 & & 12 & & 45 & 9 \\
\hline Agrenocythere & & & & & & & & & & 1 & & & 1 & & & & & & & & & & 2 & 2 \\
\hline Bythocypris & & & & & & & & & & & 2 & & & & 1 & 2 & & & & & & & 5 & 3 \\
\hline Parakrithe & & & & & & & & & & & 1 & & & & 1 & & & & & & & & 2 & 2 \\
\hline Bradleya & & & & & & & & & & & & & 2 & 1 & 2 & 4 & 9 & 12 & 30 & 13 & 14 & 9 & 96 & 10 \\
\hline Poseidonamicus & & & & & & & & & & & & & 1 & 4 & 38 & 16 & 3 & 20 & 78 & 63 & 87 & 46 & 356 & 10 \\
\hline Thalassocythere & & & & & & & & & & & & & 3 & & & & 2 & & & 1 & & & 6 & 3 \\
\hline Cytheropteron & & & & & & & & & & & & & & & 1 & & 2 & & 11 & 7 & 2 & 2 & 25 & 6 \\
\hline Argilloecia & & & & & & & & & & & & & & & 15 & 6 & 4 & & & & & 2 & 27 & 4 \\
\hline Ambocythere & & & & & & & & & & & & & & & 1 & & 3 & & 2 & 3 & 4 & 2 & 15 & 6 \\
\hline Atlanticythere? & & & & & & & & & & & & & & & & 2 & 3 & & & & & 1 & 6 & 3 \\
\hline Eucythere? & & & & & & & & & & & & & & & & 1 & & & 1 & & & & 2 & 2 \\
\hline Echinocythereis & & & & & & & & & & & & & & & & & & 1 & 1 & 8 & 5 & & 15 & 4 \\
\hline Oxycythereis & & & & & & & & & & & & & & & & & & 1 & & & & & 1 & 1 \\
\hline Submicythere & & & & & & & & & & & & & & & & & & 1 & & & & & 1 & 1 \\
\hline Rockallia & & & & & & & & & & & & & & & & & & 3 & 1 & 14 & 13 & & 31 & 4 \\
\hline Bythocythere & & & & & & & & & & & & & & & & & & & & 1 & 3 & 3 & 7 & 3 \\
\hline Abyssocythere & & & & & & & & & & & & & & & & & & & & 1 & & & 1 & 1 \\
\hline Sample population & 1 & 3 & 2 & 15 & 6 & 26 & 11 & 11 & 3 & 24 & 35 & 9 & 19 & 12 & 142 & 60 & 104 & 89 & 262 & 216 & 250 & 152 & 1452 & \\
\hline
\end{tabular}

seem to respond to some basic environmental parameters (such as temperature, mechanical energy at the sediment/ water interface, oxygen, and nutrient content) in such a way that differences in water-mass properties and major boundaries at certain depths can be estimated. The use of ostracodes as paleodepth indicators is also improving. We are especially interested in the paleodepth of the prepsychrospheric fauna, which unfortunately did not appear in Leg 72.

In this paper, we will present the census of ostracodes we have identified (Tables 1-4); a comparison of these faunas with previous ones found in DSDP cores of the southwestern Atlantic; detailed discussions of Krithe (by Peypouquet) and Poseidonamicus (by Benson) and what information they provide about the changes that have taken place; and a summary of our findings followed by systematic descriptions of new species (by Benson). This is a part of a larger ongoing study of the deep-sea fossil ostracodes of the South Atlantic sponsored by Centre National de la Recherche Scientifique (CNRS, France) and the Scholarly Research Fund (Smithsonian Institution).

The appendix at the end of this paper identifies the ostracode taxa found in Holes 516, 516F, 517, and 518 .

\section{OCCURRENCE AND DISTRIBUTION OF GENERA}

The two most abundant ostracode genera of Sites 516, 517, and 518 are Krithe and Poseidonamicus. Henryhowella, which first appears in the Eocene at Site 516 as a form similar to Wichmannella, occurs in almost all of the Oligocene and lower samples. The population size is about half (173 specimens) of that of either Poseidonamicus (356 specimens) or Krithe (474 specimens). Bradleya follows in relative abundance ( 96 specimens). Like Poseidonamicus, it first appears in the lower Mio- cene. The other ornate genera are much less abundant (Ambocythere, 15 specimens; Echinocythereis, 15 specimens; Rockallia, 31 specimens), except for Trachyleberis (45 specimens). Of the ornate genera, Poseidonamicus offers the best opportunity for a detailed study of its changing morphology. Krithe seems especially affected by oxygen tension; it will also be discussed.

Of the rare genera, the rare occurrences of Abyssocythere and Agrenocythere are noteworthy. These genera were found to be much more abundant in the deeper sites of Legs 3,39, and 40. Both genera are found in the Eocene of the Caribbean region. The upper Miocene species of Abyssocythere, A. braziliensis, which is characterized by diagonal ridges in the anterodorsal region, has been often found in deeper sites such as Hole $16(3500 \mathrm{~m})$. Agrenocythere, which formerly was considered typical of depths of about $1500 \mathrm{~m}$ (Benson, 1972), seems to have flourished at much greater depths in the southwestern Atlantic. It was found only twice at Hole $516(1300 \mathrm{~m})$, once in the Oligocene and once in the lower Miocene. It was found as early as the middle Eocene at Site 144 (Leg 14; present depth 2957 m). Agrenocythere may have existed in much deeper water than previously thought.

The very distinctive protocytherine genus Abyssocytheris, first described as a new genus from living specimens by Shornikov (1975) from 5,200 m of the Kamchatka Deep, is considered to be a "living fossil" from the middle and late Mesozoic. A rare genus (known by one of us, Benson, from at least 5 localities in the southeastern Pacific), Abyssocytheris, probably A. sulcatoperforata (Brady, 1880), is reported here for the first time in the South Atlantic (Pliocene of Hole 517, Core 12). It was first reported from the Recent of the Pacific off Juan Fernandez Islands (Brady, 1880). 
The genus Bradleya appears first at the Leg 72 sites in the lower Miocene as a robust and moderately calcified species typical of shallower and warmer parts of its range. It becomes much more delicate and less well calcified in the upper Miocene and Pliocene, which suggests a lowering of water temperatures. It appears first in the upper Eocene and Oligocene of the central Pacific and in the lower Oligocene of Site 144 in the Guiana Basin. Henryhowella and Trachyleberis similarly seem to undergo greater carbonate tension from the upper Oligocene into the middle Neogene. Their carapaces become more massive in the upper or middle Miocene, about Core 39 in Hole 516, as they begin to approach their present state of spinosity and trace reticulation. The relatively massive aspect of the Oligocene species of Agrenocythere is noteworthy. (Hole 516F, Core 12, also known from cores of Site 144 to the north).

In summary, it would seem that in Hole 516 at least four of the more important ornate genera, perhaps five if one includes Poseidonamicus, underwent an increase in the complexity of their ornamentation (a reduction of their massive appearance) at about the same time, in the early or middle Miocene. This suggests significant depth or water-mass changes. The water-mass changes are more likely, because none of these genera is presently common to depths much shallower than $1000 \mathrm{~m}$ (except possibly Trachyleberis, which does indicate shallower water; see Plate 2). The central Pacific, Caribbean, and European Tethys regions seem to have had most of the genera present before they appear in the South Atlantic. It is not yet known whether they came to the South Atlantic by way of the cooling Southern Ocean or through deep Tethyan gaps now closed. The impoverished faunas of the deeper waters sampled by Site 144 and the section at Barbados (Steineck, personal communication, 1982) suggest that the deep water mass of the central Atlantic and North Atlantic basins in the western regions were not very favorable for the proliferation of deep ostracode faunas during the Paleogene.

\section{A DETAILED EXAMINATION OF POSEIDONAMICUS}

Poseidonamicus is a relatively well-known deep-sea ostracode (Benson, 1972, 1974, 1977) from the South Atlantic, Indian, and central or eastern Pacific oceans. It is a distinctive reticulate genus that first appears in the upper Eocene of the Central Pacific (DSDP Leg 6, Hole 44 , Core 2) as a uniformly reticulate form. It soon spread into the Indian Ocean (lower Oligocene, Hole 214, Core 27) and into the South Atlantic (Oligocene, Hole 22, Core 4). The paleodepths of its species are estimated to have been at least mid-bathyal, although psychrospheric conditions forming at that time perhaps mask the actual range of paleodepths. Poseidonamicus appeared later at Site 516 (early Miocene) than at the deeper stations (Sites 357, 21, 22).

The morphologic change that takes place in Poseidonamicus from the Oligocene to the present is of particular interest to the present report because of the rearrangement of the reticulation pattern to accommodate new surface ridge structure (Plates 3 and 4 ). This change is especially well preserved with almost continual representation. The patterns of reticulation, which to the untrained eye may seem accidental, are in fact constant within a particular stage of phylogenetic development. These stages might be considered separate species for convenience although their geographic ranges have not all been determined. The individual meshes (fossae) of the reticulate pattern are controlled on a one-for-one basis by underlying cells of the shell-forming dermal tissue (Okada, 1981). This would seem to suggest that any deviation from a given pattern is a traceable genetic change. Therefore, when the meshes of Poseidonamicus subdivide or combine as the major ridges reform in their pathways through the reticular field (especially the posterolateral region) to form strengthening structures, significant evolutionary and perhaps ecologic events are recorded (Benson, 1981).

The first forms of Poseidonamicus in the lower Miocene of Holes 516 (Core 42) and 516F (Core 3) are not the oldest known from the Rio Grande Rise area. It is also known from the middle Oligocene of Holes 357 (present sea floor depth $2086 \mathrm{~m}$ ) and 22 (depth $2106 \mathrm{~m}$ ). The difference of paleodepths during the Oligocene/ Miocene transition between these sites may have been as much as $700-800 \mathrm{~m}$ and could have marked a significant water-mass change. During the Oligocene at Site 516, the fauna in general was comparatively impoverished in ornate forms, while at the deeper sites Poseidonamicus is found with Bradleya, Agrenocythere, and Rocaleberis.

The most interesting change in morphology in Poseidonamicus is the reticulation just posterior of the adductor muscle scars. The cells responsible for the individual meshes (fossae) subdivide in the lower portion of this region to allow a redirecting of the vertical elements of the reticular pattern. Whereas in the oldest representatives of Poseidonamicus (Oligocene, lower Miocene) the dominant ridges may be "latitudinal", those of the later ones (Plio-Pleistocene) become "longitudinal" or meridional. The transition period, which occurred from early through middle Miocene, was marked by forms with the strength of the reticulation carried through an emphasis of the reticulation just behind the uppermost adductor scar. One mesh is strongly "boxed in" where this particular part of the reticular pattern joins the upper three dominant columns of meshes when one lower column backs up the adductor series. Therefore, the development of the strength-giving dominant ridges is from horizontal to box-frame to vertical. The progression is from ordered to disordered back to ordered with the disordered phase supplying the necessary redundancy and mass to allow the change to take place. The oldest and most highly ordered "latitudinal" ridge and fossae system has not yet been found but probably will occur in a plicate Eocene ancestor.

The arrangement or "rearrangement" of the meshes or cells that form the reticulate pattern, and their relationship to the dominant ridges of the general architecture is especially interesting. Between the area of the adductor scars and the posteroventral spine are two columns (A and B) of meshes (in the lower Miocene forms). 
In the middle Miocene form, the front column subdivides, making a third or intermediate column $\left(\mathrm{A}^{\prime}\right)$ of meshes. Later in the Pliocene, the ridge between the old frontal column and its subdivided offspring $\left(\mathrm{A}^{\prime}\right)$ becomes strong, and that dividing the original first (A) and second column (B) begins to diminish. Eventually the intermediate column $\left(\mathrm{A}^{\prime}\right)$ and the old second column (B) combine into one ( $\left.A^{\prime} B\right)$ again leaving two columns. But this time instead of $A$ and $B$, we have $A$ and $A^{\prime}$ B. There are several other minor deviations in other parts of the pattern, but all seem to seek to allow the major pathways of strengthening the carapace to change through an alternate route as the general design is altered.

The major shift in emphasis in reticular design of Poseidonamicus seems to have taken place in the late Miocene, but because the number of specimens available diminishes at this level, it is not yet possible to define the transition more exactly. Also, the cause is still obscure, although the comparison with a similar change in Oblitacythereis described from the deep Neogene of the Mediterranean region cannot be overlooked. In this latter instance, while the Tethys Ocean circulation became more impounded by restriction in the Gibraltar region and the bathyal circulation was interrupted, the warmer waters allowed a more intense calcification and increasing redundancy in the reticulation pattern. Therefore, when the Pliocene flooding occurred, the recorded design of the invading representatives of Oblitacythereis followed a similar ridge design but a different pathway through the mesh or reticular system. We suggest that in both cases we have evidence of decreasing, and then increasing, metabolic tensions caused by shifts in water masses of differing temperatures.

In summary, Poseidonamicus first appeared in the late Oligocene with strong transverse lateral ridges (latitudinal). From late in early Miocene through middle Miocene, there was a transition during which the meshes of the central region became "boxed in". By late Miocene, which seemed to be the time of greatest stress (low populations), the dominant lateral ridge system of the posterior had become meridional. The vertical ridge was at that time partitioning parts of the reticulate field different from those it partitioned initially. These data suggest two major events: (1) the establishment of the fauna in late Oligocene and (2) a crisis at the end of the Miocene.

\section{THE PALEOHYDROLOGIC SIGNIFICANCE OF KRITHE AND PARAKRITHE}

The classification and nomenclature used here by one of us (Peypouquet, 1977-1979) has also been applied to the analysis of faunas of Leg 48 (Ducasse and Peypouquet, 1978, 1979). It takes into account the variations in dissolved oxygen of the bottom waters linked to the variations of form of the vestibule and the size of the carapace (notably the length; see Plate 5).

Table 2 contains a summary of Krithe species distribution in Holes 516 and 516F. The faunas of these two holes provide the principal, although negative results. In these Paleogene faunas, ostracodes are rare, and Krithe is absent, which seems to indicate a well-marked oxygen-minimum zone; $\mathrm{O}_{2}$ was probably less than $3 \mathrm{ml} / 1$. In faunas in the deeper holes of Sites 356 and 357 of Leg 39 and of Leg 3 from this same time (Benson, 1974, 1977), Krithe specimens show that the $\mathrm{O}_{2}$ levels were much higher. The earliest representatives of Krithe, found in Holes 516 and $516 \mathrm{~F}$, appeared in the middle Eocene (Krithe sp. C23). The $\mathrm{O}_{2}$ level was still relatively weak $\left(\mathrm{O}_{2}=3 \mathrm{ml} / \mathrm{l}\right)$. This and the appearance of Krithe sp. D21 in Hole 357 suggests a renewal of the bottom waters.

The first appearance of Krithe sp. D22 at the end of the Eocene indicates again that there was an improvement in the oxygen level from 4.5 to $5 \mathrm{ml} / 1$ in Sites 356 and 357 and in the deeper waters. It is strongly probable that the influence of the Antarctic Intermediate Water was beginning at that time. Accordingly, the absence of psychrospheric forms unambiguously indicates that this water is weak in the upper levels but much stronger in the lower depths.

The beginning of the Oligocene presents no important change compared with the terminal upper Eocene. By contrast, the end of the Oligocene and the beginning of the Miocene is marked by the appearance of Parakrithe sp. A21, indicating the increase of nutrients (especially dissolved phosphorous, Peypouquet, 1979) in the water-mass system, and by the presence of a larger vestibule in Krithe, suggesting an $\mathrm{O}_{2}$ level between 3.5 and $5 \mathrm{ml} / 1$ in the shallower depths of Holes 516 and

Table 2. Ostracode species-zone matrix for South Atlantic DSDP Site 516.

\begin{tabular}{|c|c|c|c|c|c|c|c|c|c|c|c|c|c|c|c|c|c|c|c|c|c|c|c|}
\hline \multirow[b]{3}{*}{ Taxa } & \multicolumn{19}{|c|}{$\begin{array}{c}\text { Geologic age } \\
\text { B1-zone (Benson, 1975b) }\end{array}$} & & & & \multirow{3}{*}{$\begin{array}{c}\text { Total } \\
\text { specimens }\end{array}$} \\
\hline & \multicolumn{5}{|c|}{$\begin{array}{c}\text { Cretaceous } \\
\text { Paleocene Eocene }\end{array}$} & \multicolumn{6}{|c|}{ Oligocene } & \multicolumn{8}{|c|}{ Miocene } & \multicolumn{3}{|c|}{$\begin{array}{c}\text { Plio- } \\
\text { Pleistocene }\end{array}$} & \\
\hline & 09 & 09 & 15 & 17 & 19 & 20 & 22 & 22 & 23 & 24 & 25 & $26-$ & 26 & $26+$ & 27 & 28 & 29 & 30 & 32 & 34 & 35 & 35 & \\
\hline Krithe sp. $\mathrm{C} 22$ & & & & & & 2 & & & & & & & & & 2 & 6 & 12 & & 13 & 3 & 6 & 7 & 51 \\
\hline Krithe sp. $\mathrm{C} 23$ or $\mathrm{C} 33$ & & & & 3 & & & & & & & 1 & & & & 8 & 2 & 1 & & & & & 2 & 17 \\
\hline Krithe sp. C-like D form & & & & & & & & & & 1 & & 2 & & & & & & & & & & & 3 \\
\hline Krithe sp. $\mathrm{C} 30$ or $\mathrm{C} 32$ reverse & & & & & & & & & & & & & & & & & & 3 & 1 & 2 & 4 & 4 & 14 \\
\hline Krithe sp. D21 & & & & & & 2 & & 2 & & $2^{\mathrm{a}}$ & & & $1^{\mathrm{a}}$ & & & & 3 & 8 & 7 & 1 & 9 & 1 & 36 \\
\hline Krithe sp. D22 & & & & & & & & & & & $2^{\mathrm{a}}$ & & & & & & & & & & & & 2 \\
\hline Krithe sp. D'23 & & & & & & & & & & & & & & $1^{\mathrm{a}}$ & $1^{\mathrm{a}}$ & & & & & & 8 & 10 & 20 \\
\hline Parakrithe sp. A21 & & & & & & & & & & & 1 & & & & 1 & & & & & & & & 2 \\
\hline Krithe total & & & & 3 & 1 & 4 & 2 & 4 & & 3 & 5 & 4 & 1 & 1 & 49 & 13 & 20 & 30 & 118 & 88 & 80 & 48 & 474 \\
\hline
\end{tabular}

a Small specimens (length <0.9 mm). Krithe sp. D21, Oligocene B1-Zone 24: $0.95 \mathrm{~mm}$; Miocene B1-Zone 26: 0.81 mm. Krithe sp. D22, Miocene B1-Zone 26-: 0.86 mm. Krithe sp. D'23, Miocene B1-Zone 26+: $0.85 \mathrm{~mm}$; Miocene B1-Zone 27: $0.81 \mathrm{~mm}$. 
$516 \mathrm{~F}$. It seems that the flow of deep oceanic circulation coming from the Antarctic was definitely slowing down, and that a homogenization of water coming from the North Atlantic and Tethys mixing with the Antarctic occurred. The disappearance of Krithe of the D type in the lower Miocene (Zones N4-N5) attests to a relative "stagnation" in the circulation. These observations are in agreement with those from Sites 356 and 357.

Later in the Miocene, Krithe, type D (small vestibules) reappeared, which indicates a return of well-oxygenated waters from the Antarctic and an end to the "stagnation" phase in ocean circulation. Krithe sp. C32 or C30 (characterized by a reversed hinge) first appeared at the end of the middle Miocene and the beginning of the terminal Miocene, indicating waters very rich in nutrients (Peypouquet, 1979). The fauna became very rich and diversified, approaching the composition of the present fauna. The environment at this time was very close to present conditions; all of the psychrospheric forms are represented, and there is no indication of a significant oxygen change at the end of the Miocene.

The maximal diversity of the types of Krithe that are developed in the Plio-Pleistocene are in close relationship with the diversity of those of water masses now circulating (Reid et al., 1977). Krithe type D23 (very elongated with a large vestibule) indicates an oxygenminimum zone $\left(\mathrm{O}_{2}=4 \mathrm{ml} / \mathrm{l}\right)$ forming at about 1200 $1500 \mathrm{~m}$ (close to present levels, Reid et al., 1977).

In the Quaternary specimens, the majority of the fauna is found at the bathymetric level of Hole $516 \mathrm{~F}$ $(1313 \mathrm{~m})$. They are rarer in Hole $517(2963 \mathrm{~m})$ (Table 3) and in Hole 518 (3944 m) (Table 4), and they do not appear in Hole $515(4250 \mathrm{~m})$. The history of the development of water masses, as shown by the ostracodes of the western South Atlantic, is completely different from that of the eastern South Atlantic (Peypouquet and Benson, in press). This difference may be the result of possible upwelling caused by local conditions.

\section{DISCUSSIONS AND CONCLUSIONS}

In this study of the ostracodes, two important probblems were to be addressed (Barker et al., 1981): (1) Has the postulated subsidence of the Rio Grande Rise been recorded in adaptive modifications of the ostracode

Table 3. Ostracode distribution, Site 517.

\begin{tabular}{lrcc}
\hline \multicolumn{1}{c}{ Ostracode } & Pliocene & \\
& lower & upper & Quaternary \\
\hline $\begin{array}{l}\text { Thalassocythere } \\
\text { Unidentified }\end{array}$ & 2 & 3 & 1 \\
$\begin{array}{l}\text { Abyssocythereis } \\
\text { Agrenocythere }\end{array}$ & 1 & & \\
$\begin{array}{l}\text { Henryhowella } \\
\text { Poseidonamicus }\end{array}$ & 1 & & \\
$\begin{array}{l}\text { Krithe } \text { sp. C22 } \\
\text { Krithe } \text { sp. C32 reverse }\end{array}$ & 6 & 6 & 1 \\
$\begin{array}{l}\text { Krithe sp. D21 } \\
\text { Krithe } \text { sp. D'23 }\end{array}$ & 2 & 6 & 8 \\
$\begin{array}{l}\text { Krithe } \text { sp. D12 } \\
\text { Krithe } \text { sp. D22 (like C type) }\end{array}$ & 1 & 1 & \\
Krithe total & 3 & & \\
\hline
\end{tabular}

Table 4. Ostracode distribution, Site 518.

\begin{tabular}{|c|c|c|c|c|}
\hline Ostracode & $\begin{array}{c}\text { middle } \\
\text { Miocene }\end{array}$ & $\begin{array}{c}\text { upper } \\
\text { Miocene }\end{array}$ & $\begin{array}{l}\text { lower } \\
\text { Pliocene }\end{array}$ & Quaternary \\
\hline Bradleya & 1 & & & \\
\hline Abyssocythere & & 3 & & \\
\hline Henryhowella & & 1 & 7 & \\
\hline Poseidonamicus & & 1 & 12 & 2 \\
\hline Ambocythere & & & 1 & \\
\hline Echinocythereis & & & 1 & \\
\hline Agrenocythere & & & 1 & \\
\hline Hyphalocythere & & & 1 & \\
\hline Pelecocythere & & & 2 & \\
\hline Unidentified & & & 1 & \\
\hline Thalassocythere & & & & 1 \\
\hline Krithe sp. D21 & & 2 & & 2 \\
\hline Krithe sp. D' 23 & & & 7 & \\
\hline Krithe sp. C23 & & & 4 & \\
\hline Krithe sp. C32, C30 reverse & & & & 3 \\
\hline Krithe total & & 2 & 19 & 6 \\
\hline
\end{tabular}

fauna? (2) When was the beginning of the modern deepsea circulation pattern now in part controlled by the Vema Passage? Regrettably, the ostracode evidence of Leg 72 cannot be used to demonstrate any major subsidence. Curiously, the Cretaceous and lower Paleogene sediments, identified as shallow or upper bathyal on other evidence in this report, are devoid or almost devoid of ostracodes. This is very unusual because Mesozoic sediments of shelf depth and of this particular age range are usually crowded with ostracodes and have been used for biogeographic reconstruction in adjacent shallow regions (Reyment, 1980; Bertels, 1973; Dingle, 1971). At this time, no suitable explanation can be given for their absence in the Cretaceous section of Site 516.

The depth range of the Oligocene and younger fauna is that of upper bathyal to mid-bathyal. No forms typical of lower bathyal or abyssal depths were found in most of the cores; when they did occur, they were found only as traces. There is no ostracode evidence that the depths at Site 516 were greater than at present.

The modern deep-sea circulation is marked by the presence of a thick complex of cold water masses (psychrosphere), which support the spinning, warm-water gyrals (thermosphere) near and at the surface (to a depth of about $400 \mathrm{~m}$ in low latitudes). During the Cretaceous and in the early Paleogene, the psychrosphere may have existed only in the more isolated basins to the south of the Rio Grande barrier. However, there is no direct evidence of this.

The warm-water masses formed by the Tethys circumglobal sea and ocean system kept the polar influences moderate until this restricted latitudinal system became replaced by the present open meridional system (Benson, 1979). Obviously, there could have been lags in the local development of basin faunas as barriers were penetrated in the evolution of the present more open system. The Rio Grande Rise provided a major barrier and threshold that allowed Antarctic Bottom Water into the north, primarily through Vema Passage. At the same time, this barrier and the denser Antarctic Bottom Water kept warmer, dense Tethyan water out of the depths of the southern Cape Argentine Basin complex. As the Atlantic spread apart and Tethys closed, the conflict in the deep water-mass supply reached critical 
proportions about $40 \mathrm{Ma}$. This was some considerable time after the general union of the North and South Atlantic.

The ostracode evidence from Legs 3 and 39 as well as from the first 75 sites of DSDP indicated (Benson, 1975) that the psychrosphere began to be formed during the Eocene and reached its critical stage (forming a major change in the adaptive structures of the new deep-sea species) near the end of the late Eocene. This climax, shown in the strong changes in the ostracodes, differed only in intensity and suddenness by perhaps $2-5$ million years from that described in the South Pacific by Kennett and Shackelton (1976; also Shackelton and Kennett, 1975). In general, other evidence (Douglas and Savin, 1975; Corliss, 1979) has supported the concept of such a change, as does other evidence in this report. However, the question of suddenness $(200,000$ years proposed by Kennett and Shackelton, 1976) is in our opinion still unresolved. In fact, we have described (Peypouquet and Benson, in press) a difference in timing for this event at the Walvis Ridge, which separates the very complete faunal record in the two basins (the Angola and Cape Basins) to the north and south. We believe that, when all of the evidence from the present drilling is seen, the establishment of the psychrospheric fauna will be diachronous both in depth differences and time differences extending over several millions of years.

The present evidence, especially from Site 516, suggests that normal oceanic mid-bathyal conditions did not exist until the late Oligocene. In these shallower bathyal depths (compared to abyssal depths), modern circulation patterns were only well established in terms of the modern fauna during the Miocene. Something caused abnormal stress in the upper Miocene. It is possible that this is related to the Messinian salinity crisis of the Mediterranean region, but there is still no linkage in the ostracode evidence of these events at intermediate DSDP sites.

The absence of the ostracodes from the pre-Oligocene sediments in Site 516 must be contrasted with their abundance in other deeper Sites of Legs 3, 14, 39, and 40 and their description from Africa (Dingle, 1971, 1976), Argentina (Bertels, 1973), and the Walvis Ridge area (Site 359, study in progress). Reyment (1980) and others (Thiede, 1977; Sclater et al., 1977) have postulated that the Rio Grande Rise-Walvis Ridge region was a shallow barrier or "land bridge" throughout the Late Cretaceous and into the Paleogene. Some of this model is based on ostracode evidence taken from areas adjacent to these ridges (apparently not from Dingle, 1976), but none from the DSDP sites, or from areas near them.

There is no question that proof of the paleobathymetry of the Cretaceous or lower Paleogene ostracode faunas is difficult. This difficulty arises from the obscured ancestral nature of the older taxa involved as well as the lack of direct evidence of what the true Cretaceous deep-sea fauna was like. However, there are some properties, such as blindness, predator defense structures, low mechanical strength construction, diversity, stability, and uniqueness of taxa at the generic level, that can distinguish deep from shallow forms irrespec- tive of age. The likelihood that the Cretaceous or Paleogene faunas of Legs 3 and 39 are shallow (shelf or uppermost bathyal) is remote. There is indication of a sighted ostracode nearby in the upper Oligocene Trachyleberis specimen shown in Plate 2, Figure 8, which is the only specimen with a possible eye tubercule yet found. One would need to postulate a major and sudden subsidence at the end of the Eocene to explain the change in faunas of Legs 3,39 , and 72 , and no one has suggested this. The possibility that the sites of these legs are on the paleoslopes of islands is quite another matter (Johnson and Peters, 1979). However, the direct evidence of any shallow waters from the ostracodes remains obscure or absent for this time interval. If upper slope or shelf faunas existed in mid-ocean, and it is possible on the outermost part of the Walvis Ridge, there were great depths adjacent to these islands, at the present positions of the DSDP sites. But where are the reworked shallow specimens in the deep sediments? A large land barrier such as illustrated by Reyment (1980, fig. 2) cannot be supported by the ostracode evidence of the open South Atlantic at the present time.

Most of the ostracode genera, which appeared at Site 516 with the establishment of the normal mid-bathyal in the late Oligocene and Miocene, appeared slightly earlier in the middle or early Oligocene in the cores of the deeper Site 357. This indicates that the conditions that eliminated the older deeper thermosphere fauna also controlled the entry of the new, and progressed from deep to shallow. If the AABW was forming during this time to fill in the northern basins of the Atlantic (formation of the psychrosphere), there must have been a returning, less-dense warmer water mass from Tethys. This water mass may not have been stable over bottom areas sufficiently enjoined geographically to allow for immigration into the area of Site 516. Evidence of sparseness of ostracode faunas to the north into the $\mathrm{Ca}$ ribbean area supports this hypothesis. The deeper fauna was undergoing adaptive modification and eventually worked its way into the shallower areas as the isotherms progressed upslope. Only further studies can tell if this speculation is justified.

\section{SYSTEMATIC PALEONTOLOGY}

The following abbreviated descriptions are of new taxa represented in Sites 516 and 518. These descriptions (see Sylvester-Bradley and Benson, 1971, for terminology) are intended to validate the names and give information for preliminary identification. Sizes are given in the plate captions, and the principles of classification are from Peypouquet, 1977 and 1978.

\section{Subclass OSTRACODA Latrielle, 1806 Order PODOCOPIDA Pokorny, 1953 Superfamily CYTHERACEA Baird, 1850 Family TRACHYLEBERIDIDAE Sylvester-Bradley, 1948 Genus AMBOCYTHERE van den Bold, 1957 \\ Ambocythere challengeri Benson, $\mathrm{n}$. sp. (Plate 1, Fig. 4)}

Holotype. USNM 316042, Plate 1, Figure 4.

Diagnosis. Distinguished by its many longitudinal ridges, none of which is very strong, and the lack of a prominent posterodorsal loop.

Remarks. The strong lateral ridges of $A$. stolonifera (Brady, 1880) described from the Recent of the shallow waters of Simons Bay, South Africa, are much weakened but visible in $A$. challengeri. 
Type locality. Sample 516-4-2, 80-90 cm, upper Pliocene. Distribution. Known only from the Pliocene of the South Atlantic.

\section{Genus ABYSSOCYTHERE Benson, 1971 \\ Abyssocythere braziliensis Benson, n. sp. (Plate 4, Figs. 1,3)}

Holotype. USNM 316063, Plate 4, Figures 1,3.

Diagnosis. Distinguished from other species of Abyssocythere by its bullate muri in the area of the levatum (see Benson, 1971, for terminology), subdued dorsal bullar series, and disjunct ridged ventrolateral reticulate complex.

Remarks. Somewhat intermediate in shape between $A$. casca Benson, 1972 (the type-species from the Recent of the southwest Indian Ocean), and A. atlantica Benson, 1972, from the Pleistocene of the equatorial Atlantic, but much more robust in surface ornamentation. The present form could be ancestral to either.

Type locality. Sample 518-13-1, 40-50 cm, upper Miocene.

Distribution. Known only from the upper Miocene of the South Atlantic.

\section{Genus ATLANTICYTHERE Benson, 1977 \\ Atlanticythere? carlitae Benson, n. sp. (Plate 1, Fig. 2)}

Etymology. Named for Carlita Sanford, my assistant (RHB).

Holotype. USNM 316040, Plate 1, Figure 2.

Diagnosis. Distinguished by the rounding of the subcentral tubercule, the shortened and rounded posteromedian ridge and dorsal bullae, and the absence of prominent conuli in the positions of the pore-conuli or spines.

Remarks. This species is similar to A.? micenica n. sp. in its subdued surface sculpture, but in $A$. carlitae these features are less massive and more refined. These two Miocene species seem to be related to the Paleogene and Upper Cretaceous species of Atlanticythere, but this relationship is yet to be determined. This is the second discovery of Miocene representatives of this group of forms. The Aquitainian species A.? neogenica Benson (1977), the deep form, is very reticulate and seems to represent a different lineage from $A$.? carlitae and $A$. ? miocenica, which tend to be massive. This may represent an adaptation to differences in depth; a more complete analysis of pore distributions (Theta-Rho Analysis; Benson, 1976) is needed, however.

Type locality. Sample $516-18-1,70-80 \mathrm{~cm}$, middle Miocene.

Distribution. Known only from the Miocene of the South Atlantic.

\section{Atlanticythere? miocenica Benson, n. sp. (Plate 1, Fig. 1)}

Holotype. USNM326039; Plate 1, Figure 1.

Diagnosis. Distinguished by the very massive subcentral tubercule, posteromedian ridge, ventrolateral ridge, and dorsal bullae. The surface has no prominent pore-conuli or spines.

Remarks. Similar to A.? carlitae but much more massive (see discussion under the remarks of $A . ?$ carlitae). The massiveness of this lower Miocene species could represent warmer conditions than expressed in the more delicate middle Miocene species.

Type locality. Sample 516-27-2, 60-70 cm, lower Miocene.

Distribution. Known only from the lower Miocene of the South Atlantic.

\section{Genus BRADLEYA Hornibrook, 1952 \\ Bradleya johnsoni Benson, n. sp. (Plate 3, Fig. 8)}

Etymology. Named for David Johnson of Leg 72 .

Holotype. USNM 316062; Plate 3, Figure 8.

Diagnosis. Distinguished from other species of Bradleya by its subrectangular shape and more massive reticulation, which tends to be uniformly distributed in the posterolateral region above and below a central lateral ridge of the reticulum.

Remarks. Closely related to $B$. dictyon (Brady, 1880) but is much more massive with more uniform reticulation. It is more rectangular than B. normani (Brady, 1865) whose reticular pattern is different
(Benson, 1972). This lower Miocene species, like Atlanticythere? miocenica and Poseidonamicus riograndensis, is more massive. These three species could indicate that the waters for this time or depth interval were warmer than that which came later.

Type locality. Sample 516-39-2, 64-74 cm, lower Miocene.

Distribution. Known only from the lower Miocene of the South Atlantic.

\section{Genus POSEIDONAMICUS Benson, 1972 \\ Poseidonamicus riograndensis Benson n. sp.}

(Plate 3, Figs. 5,7; Plate 4, Fig. 6)

Holotype. USNM 306061; Plate 3, Figure 7.

Diagnosis. Distinguished by the pattern of the reticulum just posterior to the area of the adductor muscle scars where there are two vertical rows of large fossae below a strong crossing median element and three to four vertical rows above the fossa just behind the uppermost adductor scar is "boxed in."

Remarks. This lower Miocene species differs from the middle and lower Miocene species $P$. miocenicus by the more open and uniformly distributed fossae in the reticulation of the posteroventral region. The reticulation pattern of this same region in the Recent species $P$. major (Benson, 1972), the type species, is all vertical rows of which the upper four merge into a lower two or three without the ridge. The same is true of $P$. pintoi from the Recent of the South Atlantic.

Type locality. Sample 516-39-2, 64-74 cm, lower Miocene.

Distribution. Known only from the lower Miocene of the South Atlantic.

\section{Poseidonamicus miocenicus Benson n. sp.}

(Plate 3, Figs. 2,3)

Holotype. USNM 316057; Plate 3, Figure 3.

Diagnosis. Distinguished by its very irregular reticular pattern in the posteroventral region, which contains as many as four elements across between the pore-conuli below the position of the median ridge.

Remarks. The pattern is transitional in character between the lower Miocene species $P$. riograndensis and the Recent species $P$. $m a$ jor. It has a strained appearance.

Type locality. Sample 516-18-2, 85-95 cm, middle Miocene.

Distribution. Known from the middle and upper Miocene of the South Atlantic.

\section{REFERENCES}

Barker, P. F., Carlson, R. L., and Shipboard Scientific Party, 1981. Deep Sea Drilling Project Leg 72: Southwest Atlantic paleocirculation and Rio Grande Rise tectonics. Bull. Geol. Soc. Am., 92: 294-309.

Benson, R. H., 1971. A New Cenozoic deep-sea genus, Abyssocythere. (Crustacea: Ostracoda: Trachyleberididae), with descriptions of five new species. Smithson. Contrib. Paleobiology, 7:1-25.

1972. The Bradleya problem, with descriptions of two new psychospheric ostracode genera, Agrenocythere and Poseidonamicus. (Ostracoda: Crustacea). Smithson. Contrib. Paleobiology, 12: 1-138.

1974. Preliminary report on the ostracodes of Leg 24. In Fisher, R. L., Bunce, E. T., et al., Init. Repts. DSDP, 24: Washington (U.S. Govt. Printing Office), 1037-1043.

1975a. Morphologic stability in Ostracoda. Bull. Am. Paleontol., 65(282):23-25.

$1975 \mathrm{~b}$. The origin of the psychrosphere as recorded in changes of deep-sea ostracode assemblages. Lethaia, 8:69-83.

1976. The evolution of the ostracode costa analyzed by "Theta-Rho difference", Proc. Fifth Int. Symp. Evol. Post-Paleozoic Ostracoda, pp. 127-139.

1977. The Cenozoic ostracode faunas of the São Paulo Plateau and the Rio Grande Rise (DSDP Leg 39, Sites 356 and 357). In Supko, P. R., Perch-Nielsen, K., et al., Init. Repts. DSDP, 39: Washington (U.S. Govt. Printing Office), 869-883.

1979. In search of lost oceans; a paradox in discovery. In Gray, J., and Boucot A. J. (Eds.), Historical Biogeography, Plate Tectonics, and the Changing Environment: Corvallis, Oregon (Oregon State University Press), pp. 379-389. 
1981. Form, function and architecture of ostracode shells. Ann. Rev. Earth Planet. Sci., 9:59-80.

Bertels, A., 1973. Ostracodes of the type locality of the lower Tertiary (lower Danian) Rocanian Stage and Roca Formation of Argentina. Micropaleontology, 19:308-340.

Brady, G. S., 1880. Report on the Ostracoda dredged by the H. M. S. Challenger. In Thomson, C. W. (Ed.), Scientific Results of the Voyages of the H. M. S. Challenger, 1873-1876, Zoology (Vol. 1): Edinburgh (Neill and Company), pp. C1-184.

Corliss, B. H., 1979. Response of deep-sea benthonic Foraminifera to the development of the psychrosphere near the Eocene/Oligocene boundary. Nature, 282:63-65.

1981. Deep-sea benthonic Foraminifera faunal turnover near the Eocene/Oligocene boundary. Mar. Micropaleontol., 6:367-384.

Dingle, R. V., 1971. Some Cretaceous ostracodal assemblages from the Agulhas Bank (South African Continental Margin). Trans. $R$. Soc. S. Afr., 39(4):393-418.

Douglas, R. G., and Savin, S. M., 1975. Oxygen and carbon isotope analyses of Tertiary and Cretaceous microfossils from Shatsky Rise and other sites in the North Pacific Ocean. In Larson, R. L., Moberly, R., et al, Init. Repts. DSDP, 32: Washington (U.S. Govt. Printing Office), 509-520.

Ducasse, O., and Peypouquet, J.-P., 1978. Les ostracodes et l'évolution paleogéographique et paléohydrologique des marges continentales de l'Atlantique nord-oriental pendant le Cenozoique. Bull. Soc. Geol. Fr. Ser. 7., 20(4):441-452.

1979. Cenozoic ostracodes: their importance for bathymetry, hydrology, and biogeography. In Montadert, L., and Roberts, D. G., et al., Init. Repts. DSDP, 48: Washington (U.S. Govt. Printing Office), 343-363.

Johnson, D. A., and Peters, C. S., 1979. Late Cenozoic sedimentation and erosion on the Rio Grande Rise. J. Geol., 87:371-392.

Kennett, J. P., and Shackleton, N. J., 1976. Oxygen isotope evidence for the development of the psychrosphere 38 million years ago. Nature, 260:513-515.

Margolis, S. V., and Kennett, J. P., 1970. Cenozoic paleoglacial history of Antarctica recorded in subantarctic deep sea cores. Am. J. Sci., 271:1-36.
Melguen, M., LePichon, X., Sibuet, J. C., 1978. Paléoenvironnement de l'Atlantic sud. Bull. Geol. Soc. Fr. Ser. 7, 20(4):471-489.

Okada, Y. 1981. Development of cell arrangement in ostracode carapaces. Paleobiology, 7(2):276-280.

Peypouquet, J.-P., 1977. Les ostracodes et al connaissance des paléomilieux profonds. Application au Cenozoique de l'Atlantique nord-oriental [Thèse Doct. es-Sciences]. Université de Bordeaux 1, No. 552.

, 1979. Ostracodes et paléoenvironnements. Methodologie et application aux domaines profonds du Cenozoique. Bull. Bur. Rech. Geol, Min., Section IV:3-79.

Peypouquet, J.-P. and Benson, R. H., 1980. Les ostracodes actuels des bassins du Cap et d'Angola: distribution bathymétrique en fonction de l'hydrologie. Bull. Inst. Geol. Bassin Aquitaine, $28: 5-12$

, in press. Les ostracodes et l'évolution des paléoenvironments de la Walvis Ridge depuis le Cretace, éléments de paléohydrographie profonde. Bull. Geol. Soc. Fr.

Reid, J. L., Nowlin, W. D., and Patzert, W. C., 1977. On the characteristics and circulation of the southwestern Atlantic Ocean. $J$. Phys. Oceanogr., 7:61-91.

Reyment, R. A., 1980. Paleo-oceanology and paleobiogeography of the Cretaceous South Atlantic Ocean. Oceanol. Acta. 3(1): 127-133.

Sclater, J. C., Hellinger, S., Tapscott, C., 1977. The paleobathymetry of the Atlantic from the Jurassic to the present. J. Geol., 85:509-552.

Shornikov, E. I., 1975. A living fossil, representative of Protocytherini (Ostracoda), from the Kurile-Kamchatka Deep. Zool. J., 54(4): 517-524.

Sylvester-Bradley, P. C., and Benson, R. H., 1971. Terminology for surface features in ornate ostracodes. Lethaia, 4:249-286.

Thiede, J., 1977. Subsidence of a seismic ridges: evidence from sediments on Rio Grande Rise (southwest Atlantic Ocean). Bull. Am. Assoc. Pet. Geol., 61:929-940.

Date of Initial Receipt: November 30, 1981 
APPENDIX

Identification of Ostracode Taxa by Hole, Sample, and Zone (for Benson ostracode zones, see Benson 1975b)

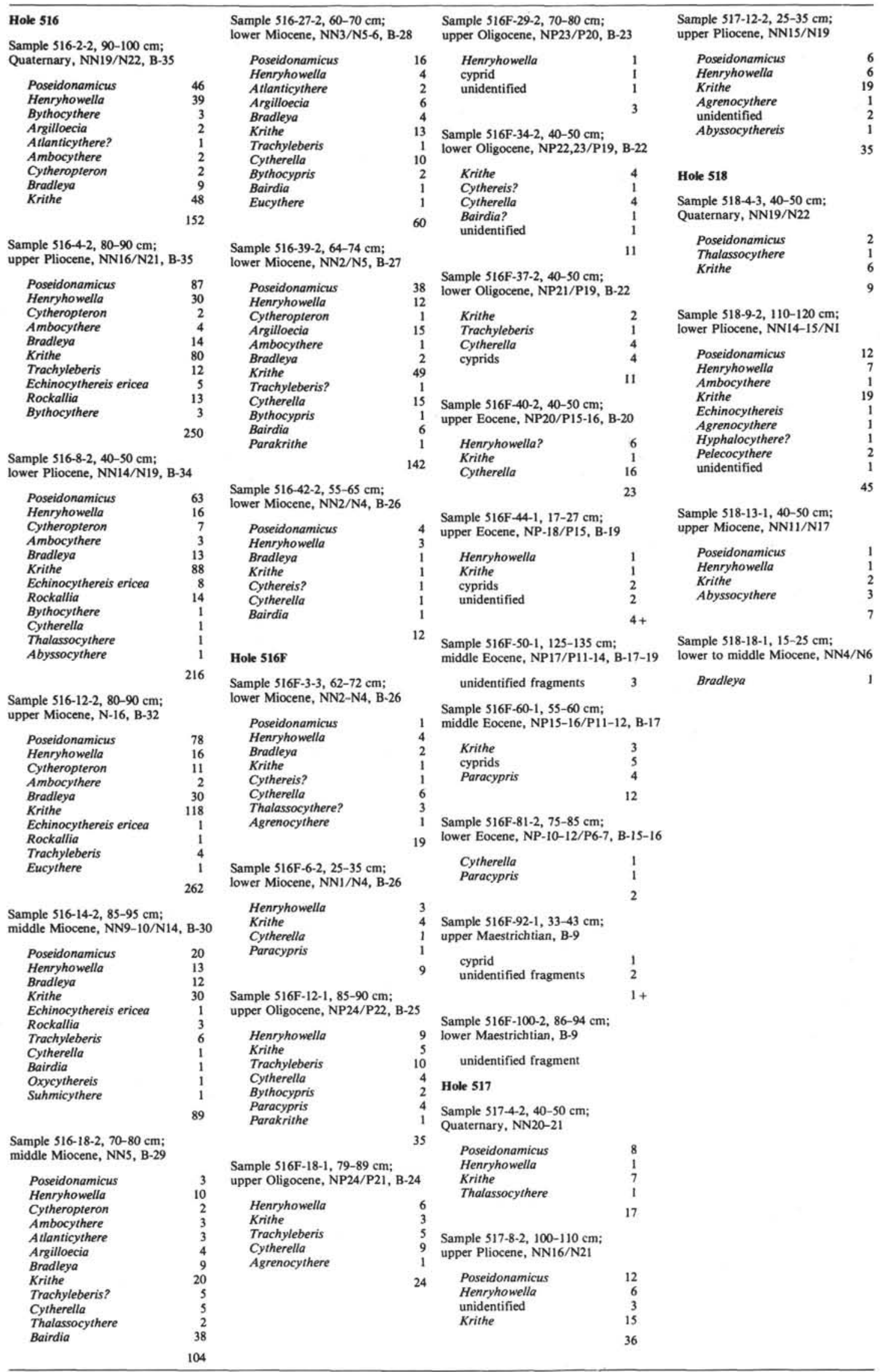



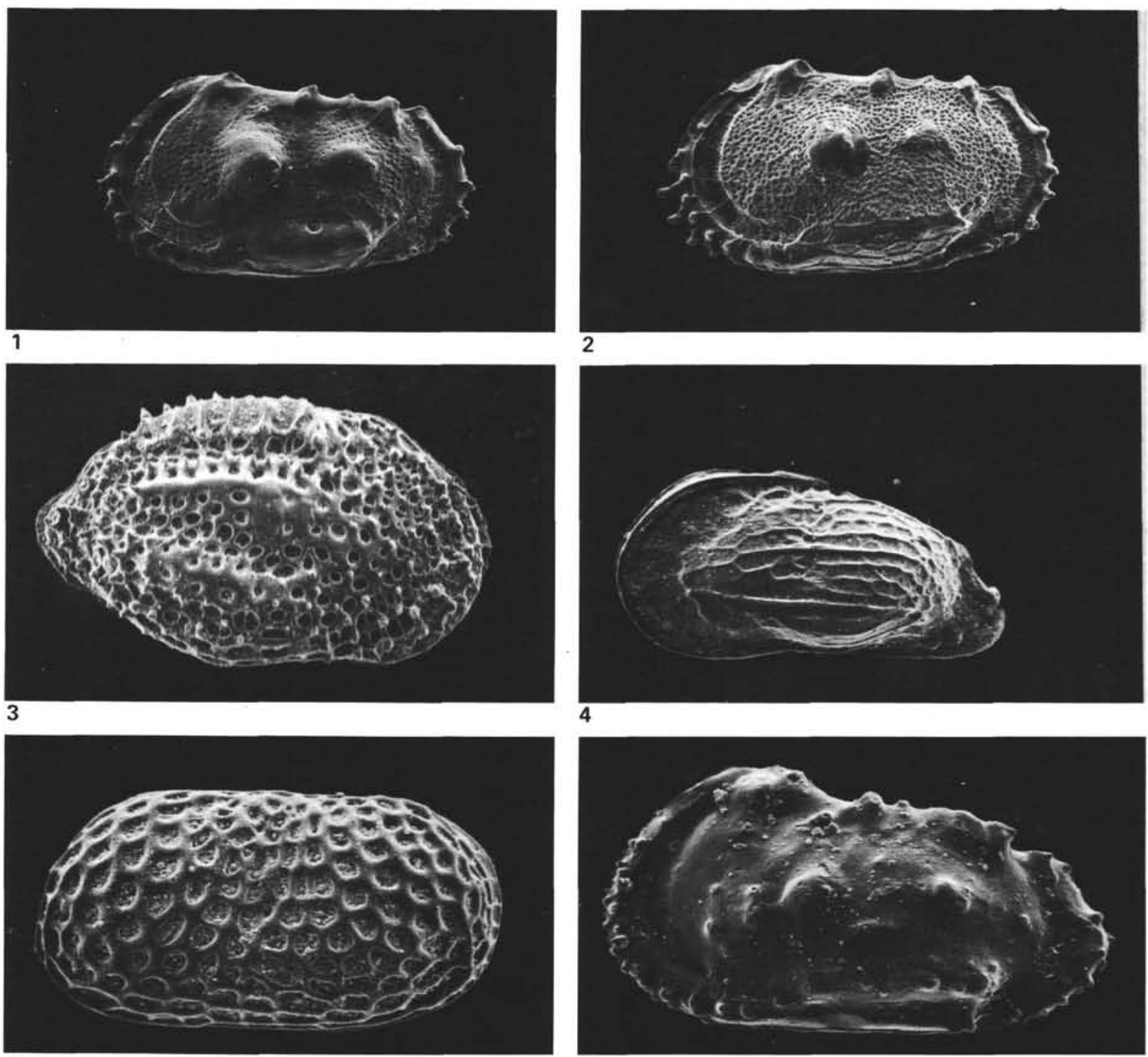

5

6
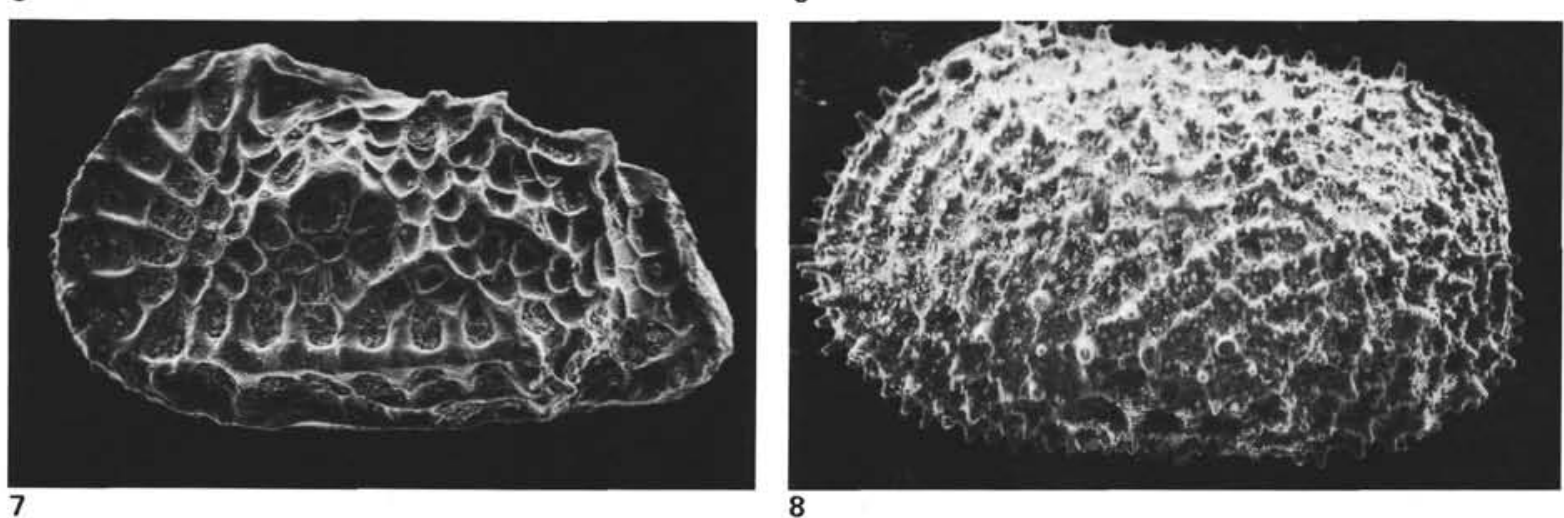

Plate 1. Ostracode species from Holes 516,516F, and 517. All magnifications by scanning electron microscope. 1. Atlanticythere? miocenica Benson, n. sp., left valve adult, $\times 65$, length $1.00 \mathrm{~mm}$; USNM 326039; Sample 516-27-2, 60-70 cm; lower Miocene; holotype. 2. A. carlitae Benson, n. sp., left valve adult, 65, length $1.08 \mathrm{~mm}$; USNM 316040; Sample 516-18-2, 70-80 cm; middle Miocene; holotype. 3. Abyssocythereis aff. A. sulcatoperforata (Brady, 1880), right valve adult, $\times 65$, length $0.80 \mathrm{~mm}$; USNM 316041; Sample 517-12-2, 25-35 cm; upper Pliocene. 4. Ambocythere challengeri Benson, $n$. sp., left valve adult male, $\times 90$, length $0.78 \mathrm{~mm}$; USNM 316042 ; Sample $526-4-2,80-90 \mathrm{~cm}$; upper Pliocene; holotype. 5. Rockallia aff. R. enigmatica Whatley, Frame, and Whittaker, 1978, left valve adult, $\times 135$, length $0.62 \mathrm{~mm}$; USNM 316043 ; Sample 516-4-2, 80-90 cm; upper Pliocene. 6-7. Sample 516F-12-1, 85-95 cm; upper Oligocene; (6) Cythereis sp., left valve adult, $\times 80$, length $1.13 \mathrm{~mm}$; USNM 316044; (7) Agrenocythere antiquata? Benson, 1972, left valve adult, $\times 65$, length $1.30 \mathrm{~mm}$; USNM 316045 . 8. Echinocythereis ericea (Brady, 1880), left valve adult, $\times 70$, length $1.30 \mathrm{~mm}$; USNM 316046, Sample 516-8-2, 40-50 cm; lower Pliocene. 


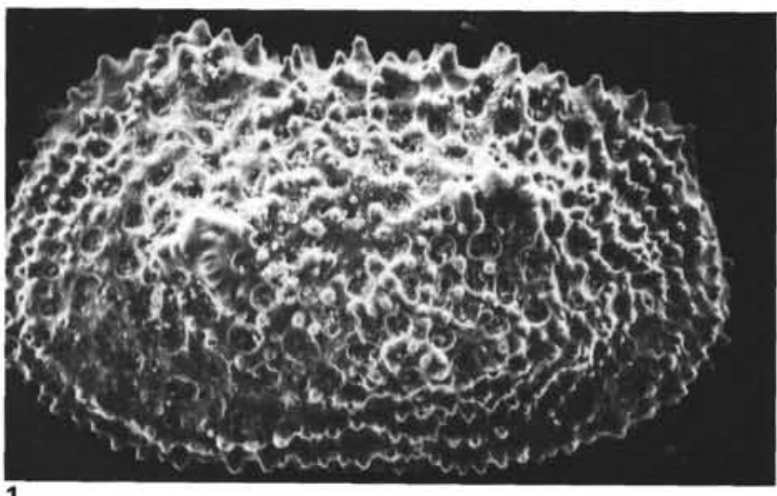

1

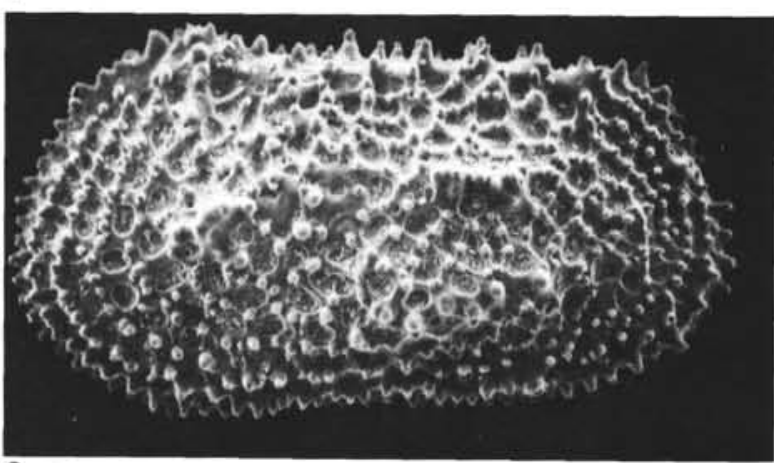

3

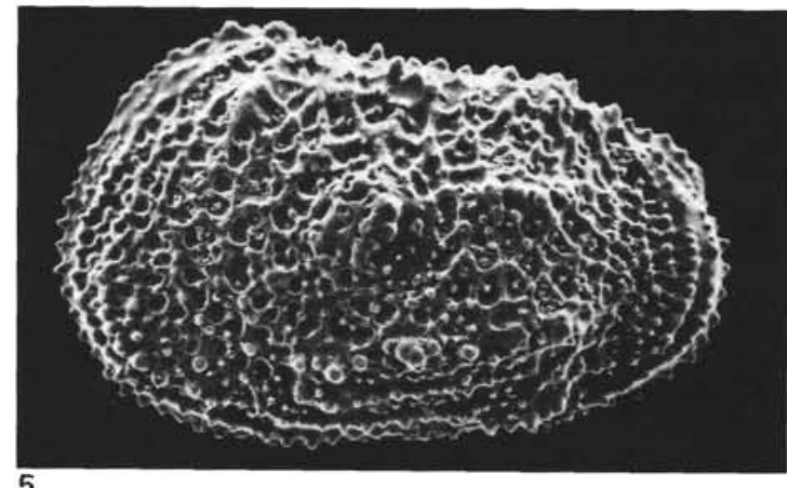

5

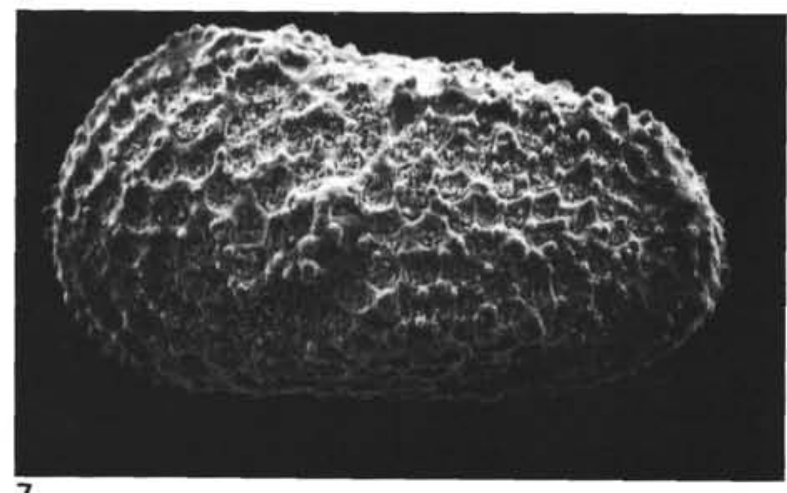

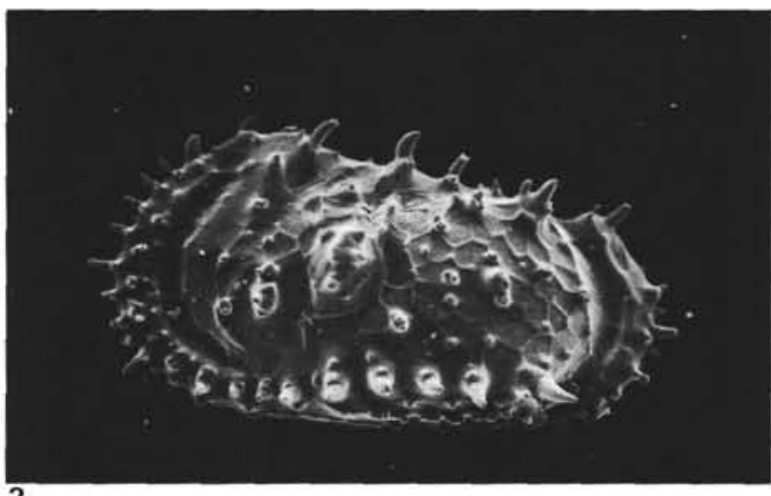

2

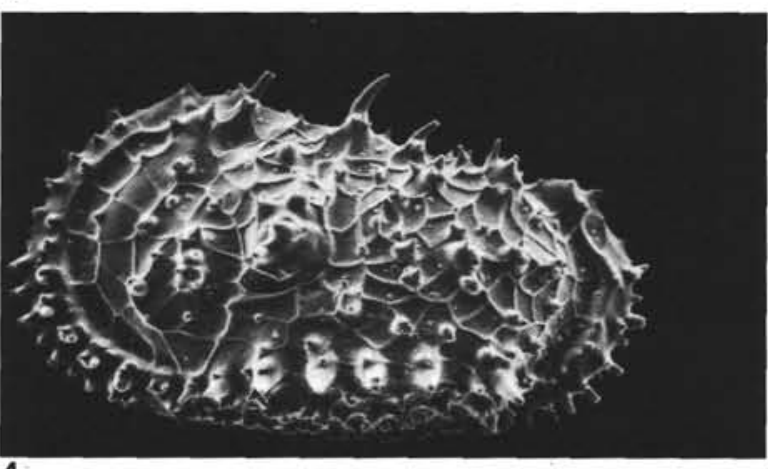

4

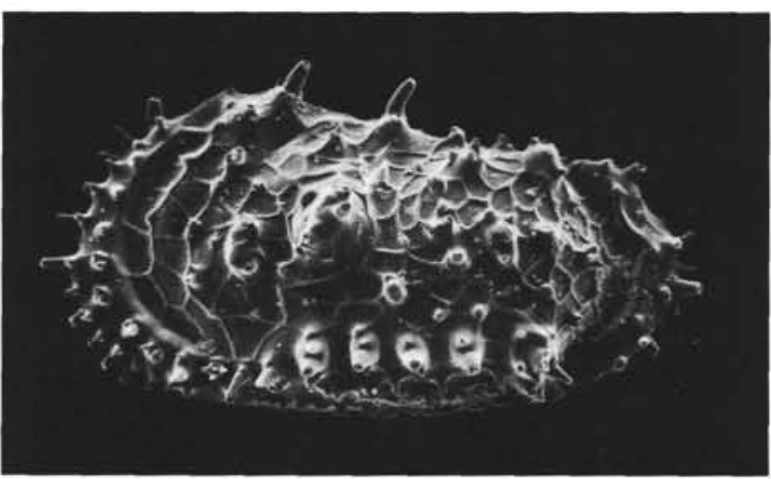

6

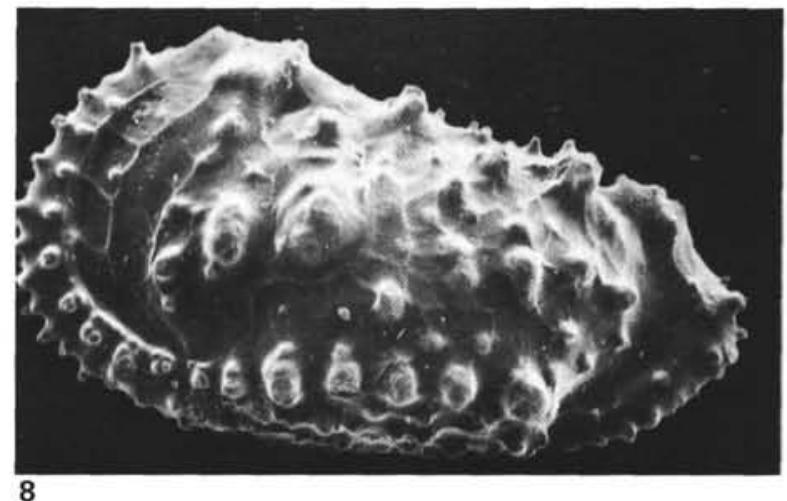

Plate 2. Ostracode species from Holes 516 and 516F. Magnifications per scanning electron microscrope. 1-2. Sample 516-4-2, 80-90 cm, upper Pliocene, (1) Henryhowella asperrima? Reuss, 1859, left valve adult female, $\times 105$, length $0.90 \mathrm{~mm}$; USNM 316047, (2) Trachyleberis sp., left valve adult, $\times 50$, length $1.45 \mathrm{~mm}$; USNM 316048, eye tubercule absent. 3. Henryhowella asperrima? Reuss, 1850, left valve adult male, $\times 90$, length $1.00 \mathrm{~mm}$, USNM 316049, Sample 516-8-2, $40-50 \mathrm{~cm}$, lower Pliocene. 4. Trachyleberis sp., left valve adult, $\times 60$, length $1.33 \mathrm{~mm}$, USNM 316050, Sample 516-14-2, 85-95 cm, upper Miocene, eye tubercule vestigial. 5. Henryhowella aff. H. asperrima Reuss, 1850, left valve adult?, $\times 110$, length $0.77 \mathrm{~mm}$, USNM 316051 , Sample 516-39-2, 64-74 cm, lower Miocene. 6. Trachyleberis sp., left valve adult, $\times 60$, length $1.30 \mathrm{~mm}$, USNM 316052, Sample 516-18-2, 70-80 cm, middle Miocene, eye tubercule questionable. 7. Henryhowella? sp., left valve adult male, $\times 110$, length $0.77 \mathrm{~mm}$, USNM 316053 , Sample $516 \mathrm{~F}-40-2,40-50 \mathrm{~cm}$, upper Eocene, very close to Wichmannella. 8. Trachyleberis sp., left valve adult, $\times 80$, length $1.13 \mathrm{~mm}$, USNM 316054, Sample 516F-18-1, 79-89 cm, upper Oligocene, possible eye tubercule. 

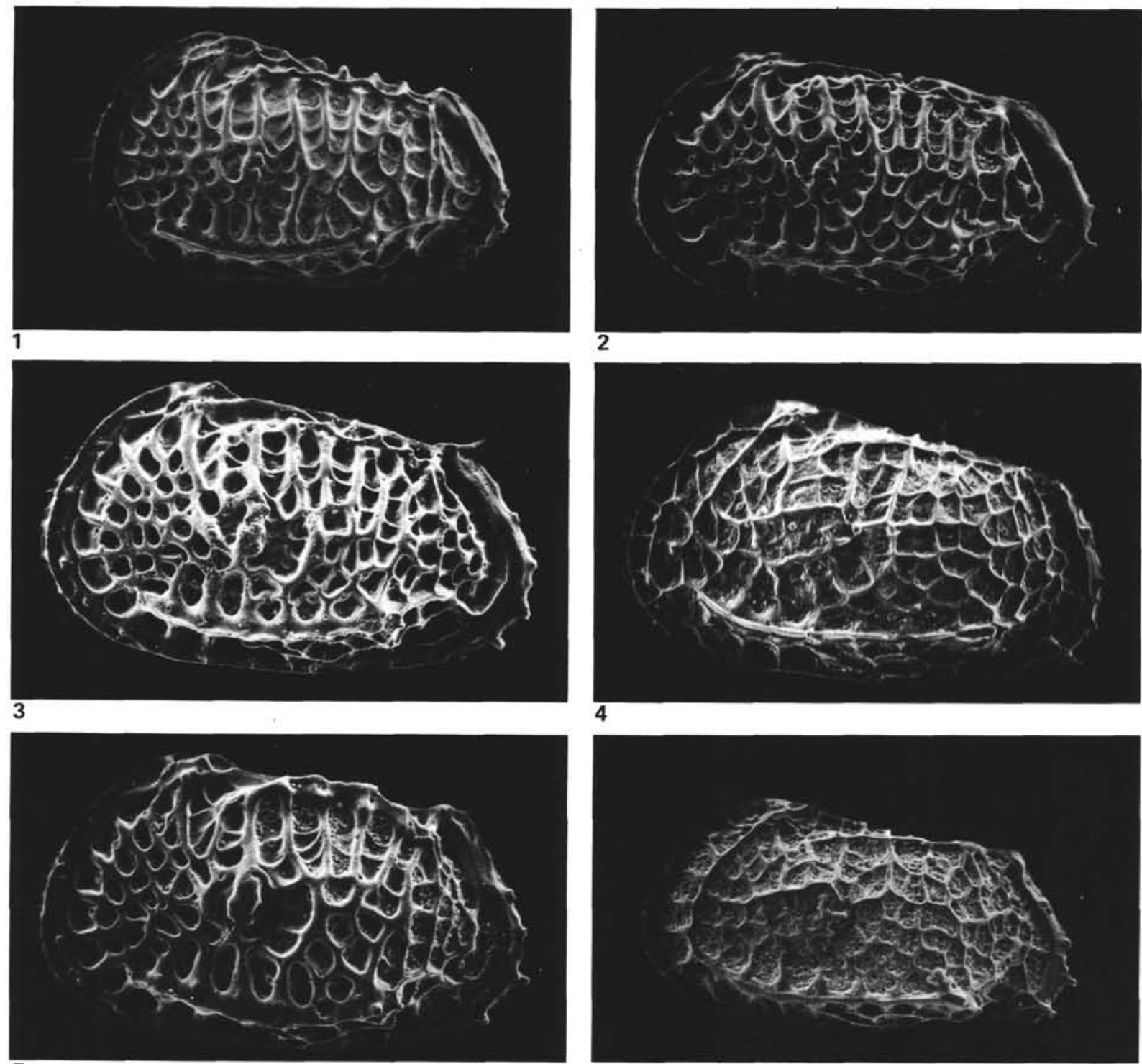

5
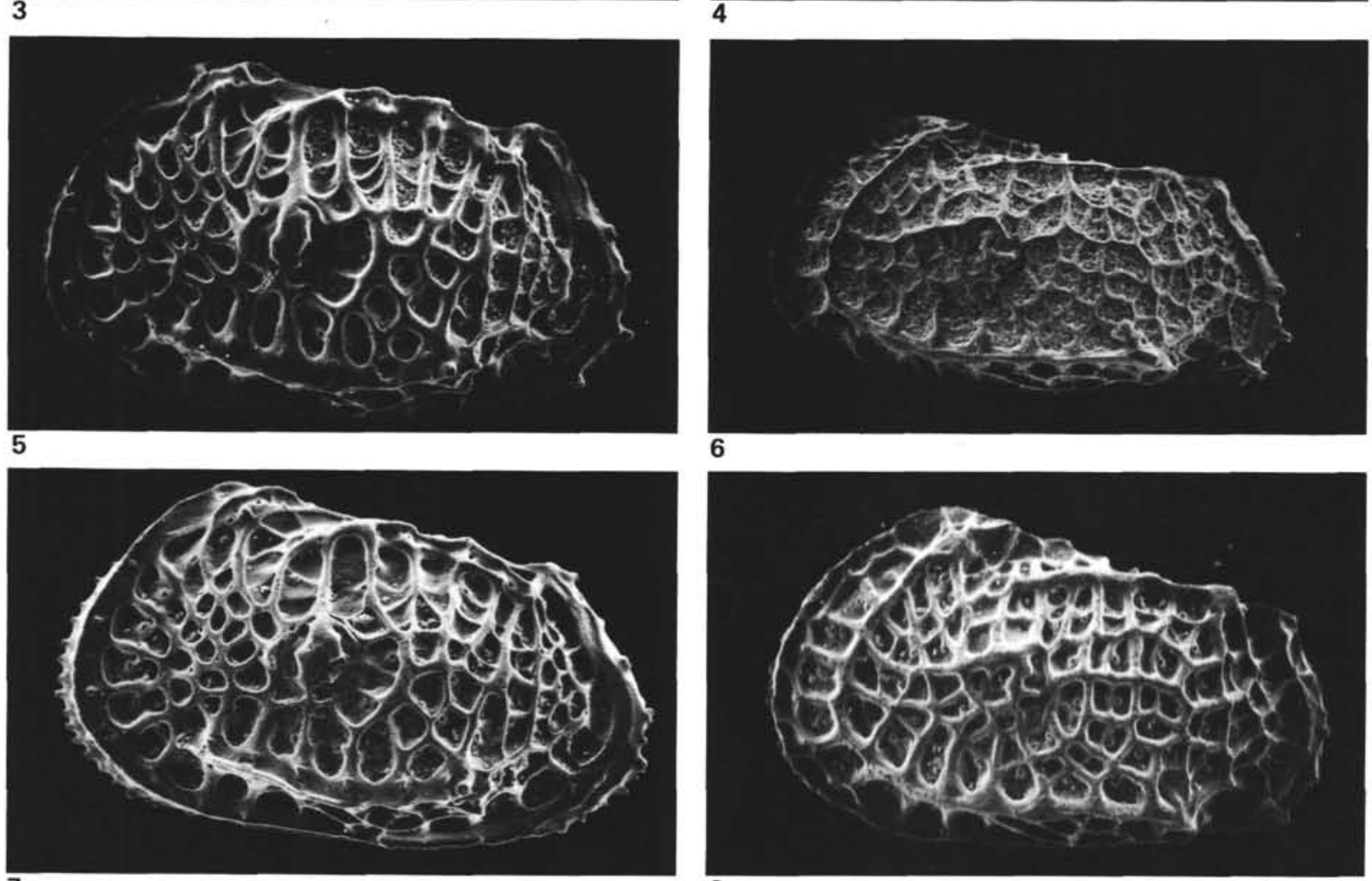

6

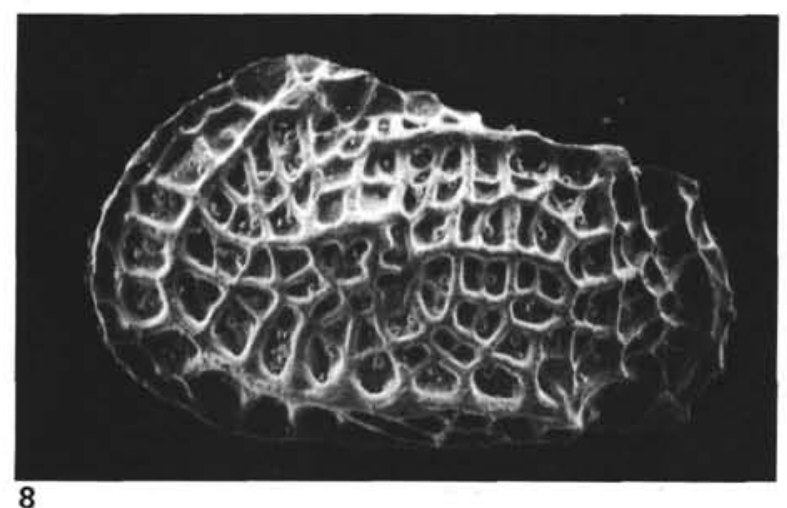

Plate 3. Ostracode species from Hole 516. Magnifications per scanning electron microscope. 1. Poseidonamicus aff. P. major Benson, 1972, left valve adult male?, $\times 65$, length $0.89 \mathrm{~mm}$, USNM 316055, Sample 516-2-2, 90-100 cm, Quaternary. 2. $P$. miocenicus Benson, n. sp., left valve adult male, $\times 80$, length $1.00 \mathrm{~mm}$, USNM 316056, Sample 516-14-2, $85-95 \mathrm{~cm}$, upper Miocene. 3. $P$. miocenicus Benson, n. sp., left valve adult female, $\times 90$ length $0.94 \mathrm{~mm}$, USNM 316057, Sample 516-18-2, 70-80 cm, middle Miocene, holotype. 4. Bradleya dictyon (Brady, 1880 ), left valve penultimate instar, $\times 80$, length $1.06 \mathrm{~mm}$, USNM 316058 , Sample $516-4-2,80-90 \mathrm{~cm}$, upper Pliocene. 5. $P$. riograndensis Benson, n. sp., left valve adult female, $\times 100$, length $0.85 \mathrm{~mm}$, USNM 316059 , Sample 516-27-2, $60-70 \mathrm{~cm}$, lower Miocene. $6 . B$. sp., left valve adult male, $\times 65$, length $1.15 \mathrm{~mm}$, USNM 316060, Sample 516-18-2, 70-80 cm, middle Miocene. 7. P. riograndensis Benson, $\mathrm{n}$. sp., left valve adult female, $\times 100$, length $0.85 \mathrm{~mm}$, USNM 316061, Sample 516-39-2, 64-74 cm, lower Miocene, holotype. 8. B. johnsoni, Benson, n. sp., left valve adult female, $\times 80$, length $1.00 \mathrm{~mm}$, USNM 316062, Sample 516-39-2, 64-74 cm, lower Miocene. 

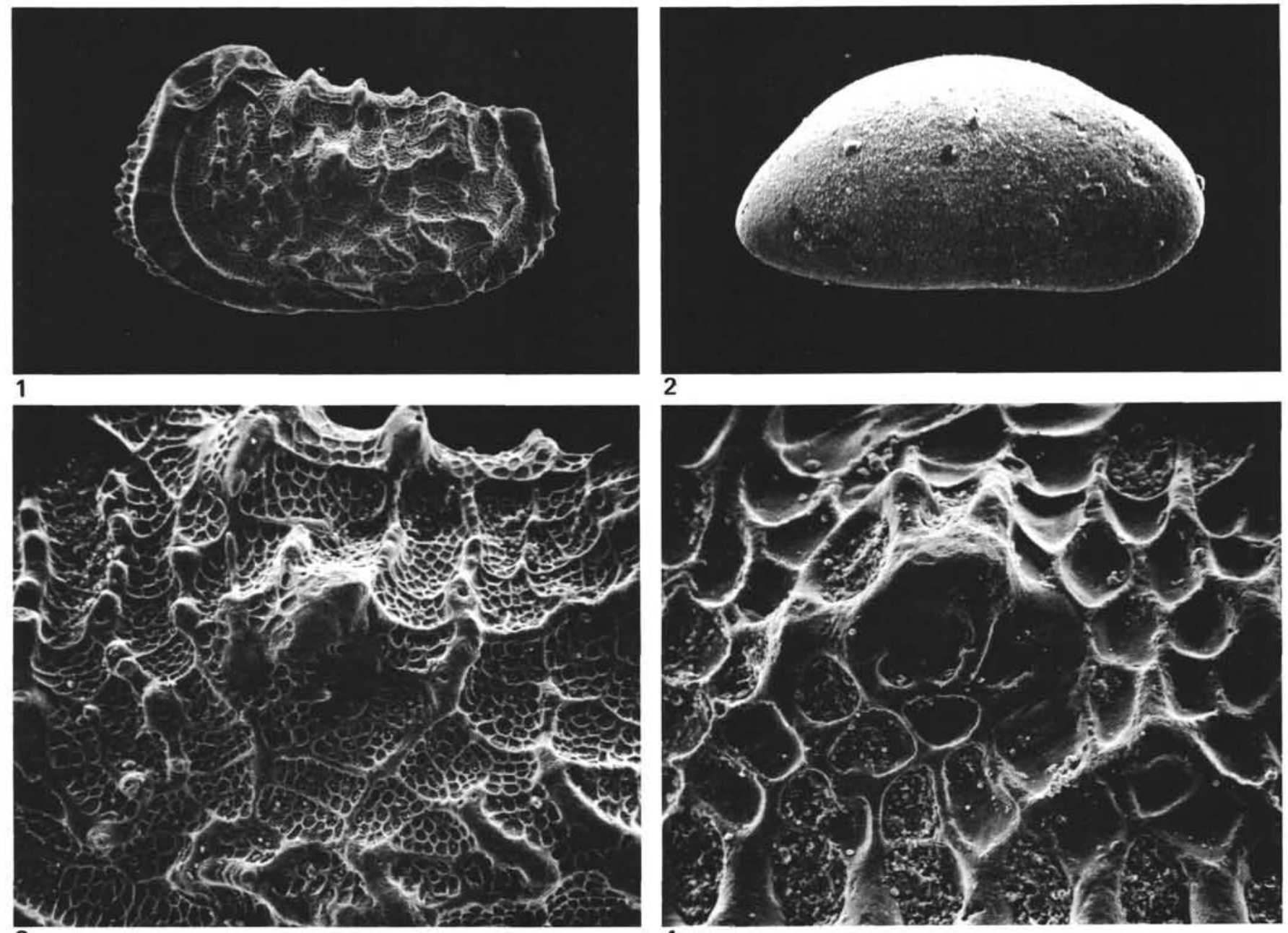

3

4
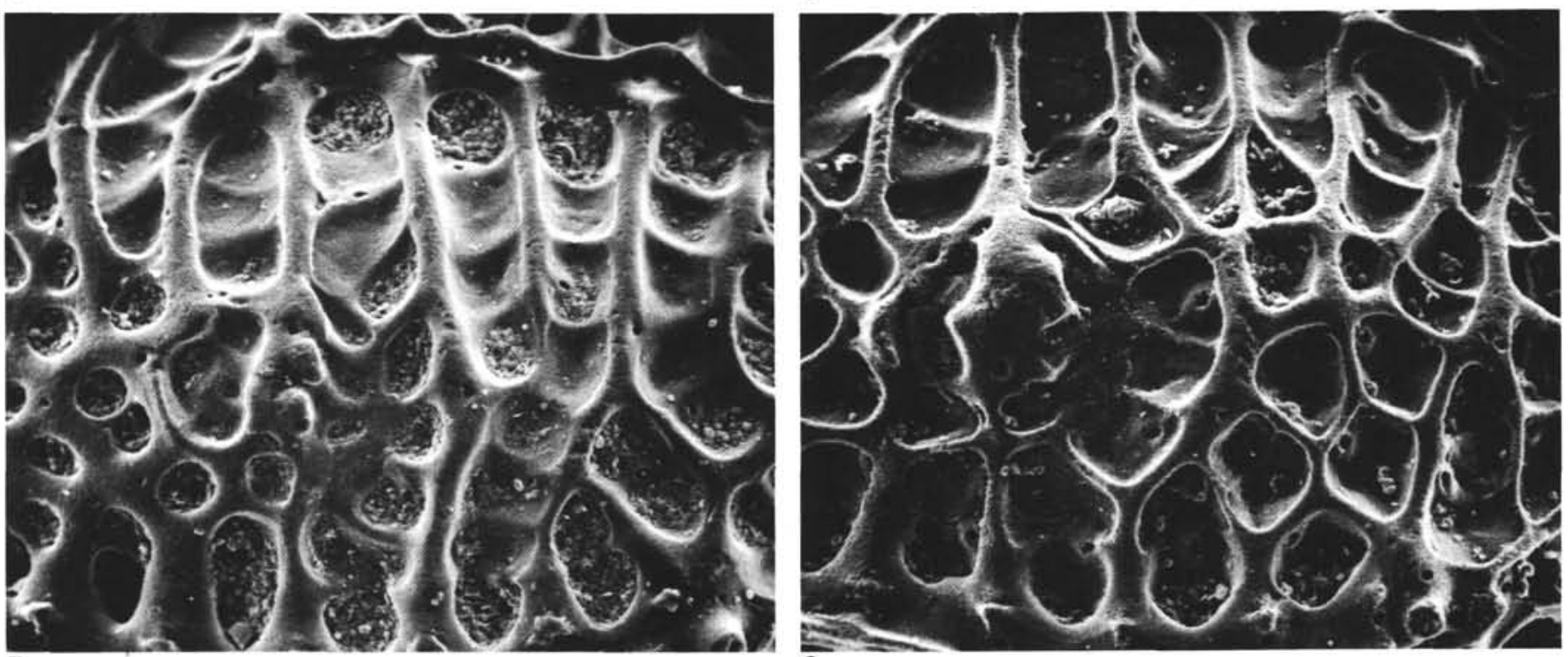

5

6

.Plate 4. Ostracode species from Holes 516, 516F, and 518. Magnifications per scanning electron microscope. 1, 3. Abyssocythere braziliensis Benson, n. sp., left valve adult male?, ×65, length $1.08 \mathrm{~mm}$, USNM 316063, Sample 518-13-1, 40-50 cm; upper Miocene, holotype, (3) central portion enlarged $\times 180$. 2. Paracypris sp., right valve adult?, $\times 105$, length $0.71 \mathrm{~mm}$, USNM 316064 , Sample $516 \mathrm{~F}-81-2,75-85 \mathrm{~cm}$, lower Eocene. 4. Agrenocythere antiquata? Benson, 1972, USNM 316053, Sample $516 \mathrm{~F}-40-2,40-50 \mathrm{~cm}$, upper Eocene, central portion enlarged, $\times 180$.

5. Poseidonamicus aff. $P$. major Benson, 1972, USNM 316055, Sample 516-2-2, 90-100 cm, Quaternary, central portion enlarged, $\times 180$. 6 . $P$. riograndensis, Benson, n. sp., USNM 316061, Sample 516-39-2, 64-74 cm, lower Miocene, central portion enlarged, $\times 220$. 

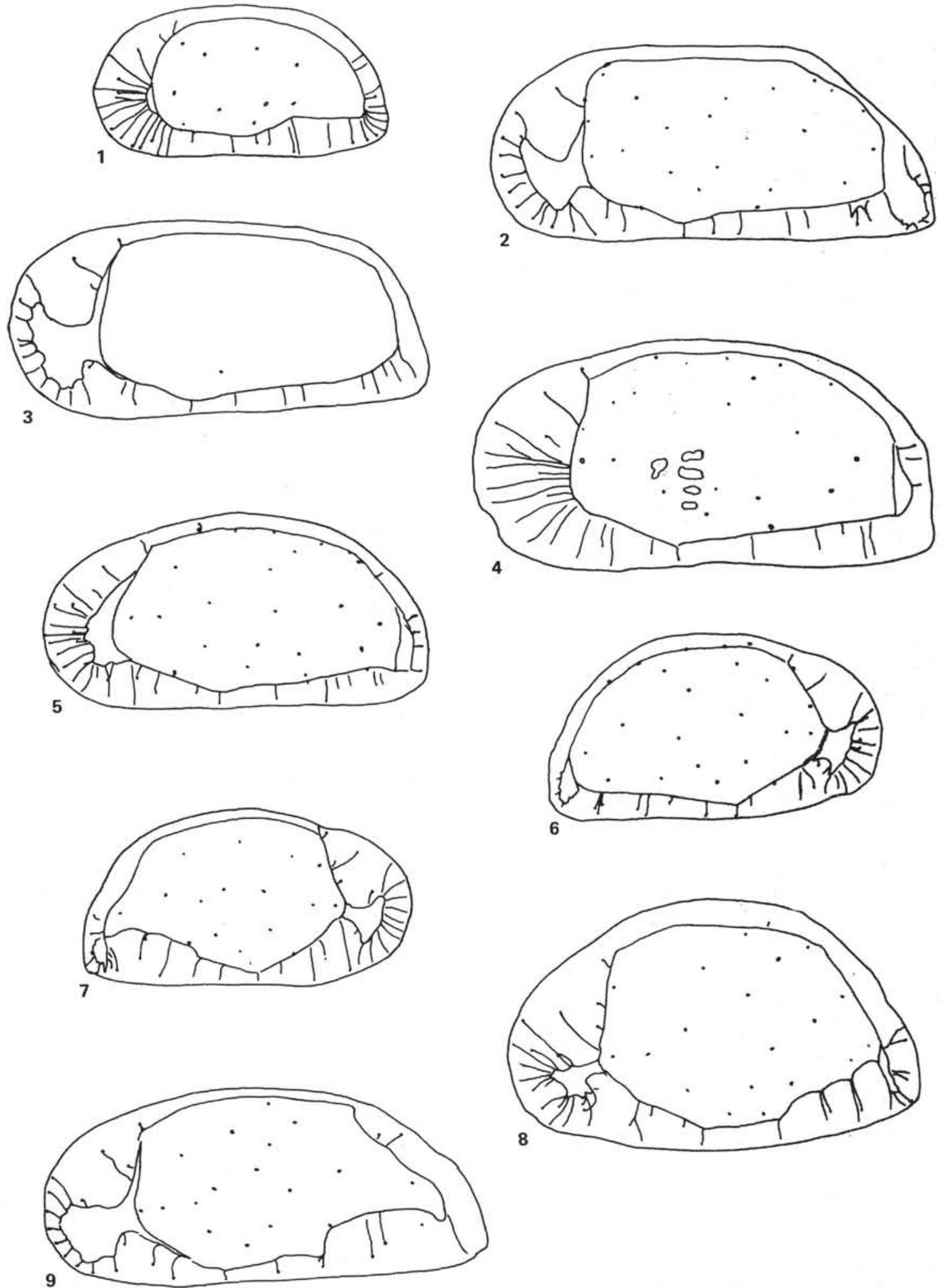

Plate 5. Parakrithe and Krithe "species" from Holes 516, 516F, 517, and 518. Magnification $\times 65$. 1. Parakrithe sp. A20, Peypouquet, right valve adult, length $0.50 \mathrm{~mm}$, height $0.26 \mathrm{~mm}$, Sample $516 \mathrm{~F}-12-1,85-90 \mathrm{~cm}$; upper Oligocene. 2,9. Sample $516-2-2,90-100 \mathrm{~cm}$, Quaternary, (2) Krithe sp. C 22. Peypouquet, right valve adult, length $0.83 \mathrm{~mm}$, height $0.37 \mathrm{~mm}$; (9) Krithe sp. D23 (new type), Peypouquet, right valve adult, length $1.01 \mathrm{~mm}$, height $0.45 \mathrm{~mm}$. 3. Krithe sp. C23, Peypouquet, right valve adult, length $0.78 \mathrm{~mm}$, height $0.37 \mathrm{~mm}$, Sample $516-39-2,64-74$ $\mathrm{cm}$, lower Miocene. 4-5. Krithe sp. C30, Peypouquet, right valve adult, reverse hinge, (4) length $1.09 \mathrm{~mm}$, height 0.54 mm, Sample 518-4-3, 40-50 cm, Quaternary; (5) length $0.92 \mathrm{~mm}$, height $0.46 \mathrm{~mm}$, Sample 517-12-2, 25-35 cm, upper Pliocene. 6. Krithe sp. C23? (like D type), Peypouquet, left valve adult, length $0.76 \mathrm{~mm}$, height $0.45 \mathrm{~mm}$, Sample 517F-6-1, 25-35 cm, lower Miocene. 7 . Krithe sp. D12 (like C type), Peypouquet, left valve adult, length $0.76 \mathrm{~mm}$, height $0.41 \mathrm{~mm}$, Sample $517-4-2,40-50 \mathrm{~cm}$, Quaternary. 8. Krithe sp. D21, Peypouquet, right valve adult, length $0.93 \mathrm{~mm}$, height $0.59 \mathrm{~mm}$, Sample 516-12-2, $80-90 \mathrm{~cm}$, upper Miocene to lower Pliocene. 